\title{
TATA KELOLA KELAUTAN BERDASARKAN INTEGRATED COASTAL AND OCEAN MANAGEMENT UNTUK PEMBANGUNAN KELAUTAN BERKELANJUTAN
}

\author{
Dina Sunyowati \\ Fakultas Hukum \\ Universitas Airlangga Surabaya
}

\begin{abstract}
Abstrak
Pembangunan Kelautan pada dasarnya harus memperhatikan lingkungan laut secara keseluruhan, termasuk wilayah pesisir, karena lingkungan laut yang menjadi komponen penting dalam mendukung kehidupan sistem global dan aset positif dirinya untuk kesempatan oleh pembangunan berkelanjutan. Pembangunan kelautan berkelanjutan, diimbangi pembangunan ekonomi dan lingkungan yang mendukung kapabilitas baik di pantai atau di laut, berdasarkan Agenda 21 Bab 17. Kebijakan laut nasional meliputi 2 (dua) dimensi kepentingan nasional dan otoritas kedaulatan dan yurisdiksi, dan bunga Indonesia dan keterlibatan pada peraturan global dalam hukum internasional. Dicari aturan akan terwujud dalam bentuk tata kelola laut sebagai instrumen kebijakan laut. Tujuan yang ingin dicapai dalam konsolidasi pemerintahan laut adalah pembentukan pemerintahan laut baik di tingkat nasional, sehingga akan dapat koordinasi dan sinkronisasi pembangunan laut dalam setiap sektor, mulai dari perencanaan, pelaksanaan, monitoring dan evaluasi.

Kata Kunci: Lingkungan Laut, Good Governance Samudra, Pesisir dan Lautan Terpadu Manajemen
\end{abstract}

\begin{abstract}
Marine development basically must pay attention to marine environment as a whole, including its coastal zones, because marine environment that become the important component of global life support system and positive asset itself to opportunity by sustainable development. Sustainable marine development, balanced out economic development and support capability environment whether in coastal or in the marine, based on Agenda 21 Chapter 17. National ocean policy includes 2 (two) dimensions is national interest and authority of sovereignty and jurisdiction, and Indonesian interest and involvement at global regulations in international law. Wanted rules will be realized in the form of ocean governance as the instrument of ocean policy. The purpose that want to be reached out in consolidation of ocean governance is the establishment of good ocean governance in the national level, therefore it will be able to coordination and synchronize the ocean development in every sector, start from its planning, implementation, monitoring and evaluation.
\end{abstract}

Keywords: Marine Environment, Good Ocean Governance, Integrated Coastal and Ocean Management

Tata Kelola Kelautan Berdasarkan 


\section{PENDAHULUAN}

Pada tanggal $11-15$ Mei 2009 World Ocean Conference (WOC/ Konferensi Kelautan Dunia) diadakan Manado, Sulawesi Utara. WOC didakan di Indonesia dengan dukungan penuh dari Pemerintah Indonesia, UNEP dan organisasi internasional lainnya yang bergerak di bidang lingkungan. Konferensi ini merupakan acara yang sangat prestisius dan akan membawa pengaruh dan image dunia terhadap perkembangan kelautan dan lingkungan laut di Indonesia. Konferensi membahas mengenai kebijakan kelautan global, khususnya draft Manado Ocean Declaration (MOD) dan dihadiri oleh para Kepala Negara, para Menteri terkait di bidang kelautan, utusan Negara-negara, Wakil Diplomatic dan Konsuler Negara-negara sahabat serta organisasi internasional yang terkait dengan kelautan, seperti USAID, National Oceanic and Atmospheric Administration (NOAA), World Wide Foundation (WWF), The Nature Conservancy (TNC), Conservancy International (CI), dan UNESCO.

\section{Manado Ocean Declaration} (MOD) terdiri atas 14 paragraf pembuka inti dan 21 poin kesepakatan operatif. Isi deklarasi antara lain berupa komitmen negara-negara peserta untuk melakukan konservasi laut jangka panjang,

Tata Kelola Kelautan Berdasarkan menerapkan manajemen pengelolaan sumber daya laut dan daerah pantai dengan pendekatan ekosistem, serta memperkuat kemitraan global untuk pembangunan berwawasan lingkungan.

Kesepakatan yang tertuang dalam MOD akan menyatukan tujuan negara-negara peserta konferensi untuk menjadikan laut sebagai arus utama dalam setiap pembahasan dan negosiasi terkait perubahan iklim, kerja sama riset ilmiah untuk merumuskan strategi adaptasi yang tepat dalam rangka mengurangi dampak perubahan iklim terhadap laut dan mekanisme pendanaan dalam upaya adaptasi dan mitigasi dampak perubahan iklim terhadap laut dan sebaliknya. Selain itu diperlukan strategi nasional untuk pengelolaan ekosistem laut dan kawasan pantai serta penerapan pengelolaan laut dan daerah pantai secara terpadu, penerapan kebijakan terpadu yang ramah lingkungan dalam pengelolaan laut dan daerah pantai dengan memperhatikan kehidupan masyarakat yang paling rentan, yakni mereka yang hidup di pesisir atau pantai dengan menekankan pada dukungan finansial dan insentif untuk mewujudkan lingkungan yang baik.

Menyadari pentingnya pembangunan kelautan di Indonesia dan sebagai implementasi kesepakatan MOD, tulisan ini dibuat sebagai 
sumbang saran dalam upaya menata kelola laut di Indonesia berdasarkan konferensi-konferensi yang diadakan oleh Negara-negara sejak tahun 1992 tentang pembangunan berkelanjutan termasuk didalamnya pembangunan kelautan berkelanjutan.

Salah satu hasil United Nations Conference on Environment and Development (UNCED) di Rio de Janeiro tahun 1992, adalah Agenda 21. UNCED memasukkan Ketentuan yang terkait dengan pengelolaan wilayah pesisir dan laut (integrated coastal and ocean management) dalam Agenda 21 Chapter 17 sebagai rencana kerja di Abad 21 dengan judul "Protection of the Oceans, All Kinds of Seas, including Enclosed and Semi-enclosed Seas, and Coastal Areas, and the Protection, Rational Use and Development of Their Living Resources".

Pengelolaan wilayah pesisir dan laut secara terpadu (integrated coastal and ocean management) merupakan pendekatan baru bahwa lingkungan laut (the Marine Environment) merupakan komponen penting sistem penyangga kehidupan global. (Rochmin Dahuri I;2001;5) Chapter 17, program (a) tentang "Integrated management and sustainable development of coastal areas, including exclusive economic zones", menjadi fokus utama dan kesepakatan negara-negara maritim dengan mengembangkan pengelolaan pesisir dan laut secara integral dan berkelanjutan, dalam arti tidak hanya mengelola pesisir dan laut dengan sebagian lautnya, tetapi juga mengelola dan melindungi wilayah laut keseluruhannya seperti terdapat dalam United Nations Convention on the Law of The Sea (UNCLOS ) 1982, mulai dari perairan pedalaman, laut teritorial, zona tambahan, zona ekonomi eksklusif, landas kontinen, area/kawasan dan laut bebas sesuai dengan integrated coastal management dan sustainable development.

Kebutuhan akan perlunya pengaturan mengenai pengelolaan wilayah pesisir dan laut di Indonesia muncul setelah dituangkannya Agenda 21 Global dalam Agenda 21 Indonesia Tahun 1996. Implementasi integrated coastal and ocean management relatif masih kurang dilaksanakan dalam pengelolaan sumberdaya alam di wilayah pesisir dan laut Indonesia. Sedangkan pembangunan sumberdaya pesisir dan laut secara optimal dan berkelanjutan hanya dapat diwujudkan melalui pendekatan holistik dan terintegasi.

Kebijakan dan strategi dalam pembangunan sumberdaya kelautan berdasar pada integrated coastal and ocean management, dihasilkan dari suatu proses politik, dalam pengertian bahwa kebijakan tersebut tersusun dan 
diimplementasikan melalui proses negosiasi antar berbagai stakeholders. Oleh karena itu, keberhasilan segenap kaidah pembangunan berkelanjutan yang baik sangat tergantung pada kemauan dan komitmen segenap stakeholders, baik dalam lingkup nasional maupun lintas batas.

Kerangka kebijakan kelautan berkelanjutan Indonesia disusun dengan pendekatan pada tata kelola kelautan (ocean governance) dan integrated coastal and ocean management. Pengertian ocean governance diarahkan untuk dapat mewujudkan bentuk rancang bangun dan upaya yang dilakukan dalam mengatur kegiatan publik pada wilayah laut beserta pemanfaatan sumber daya alam yang terkandung di dalamnya.

Integrated coastal and ocean management berisi prinsip-prinsip yang terkait dengan pengelolaan sumberdaya pesisir dan laut, integrasi peraturan perundang-undangan dan integrasi antar sektor. Tata kelola kelautan dibangun secara sistemik melalui pengembangan dan pemahaman keterpaduan antara pengelola di wilayah pesisir dan laut dengan pihak-pihak terkait, adanya tujuan dan sasaran, nilai dan etika dalam pembangunan, serta upaya penyelesaian sengketa dan kerjasama diantara masyarakat pesisir, pemerintah dan stakeholders.

Berdasarkan Agenda 21 Chapter 17 Program (a), Pengelolaan wilayah pesisir dan laut bertumpu pada prinsip-prinsip dalam integrated coastal and ocean management, dan harus dirumuskan dalam suatu bentuk aturan hukum. Untuk itulah bentuk/formulasi aturan hukum pengelolaan sumberdaya pesisir dan laut harus berdasarkan pada prinsip good ocean governance. Keberadaan Undang-undang Nomor 27 Tahun 2007 tentang Pengelolaan Wilayah Pesisir dan Pulau-pulau Kecil (selanjutnya disebut PWP-PK) harus menjadi acuan bagi pembentukan perangkat hukum pelaksanaan pengelolaan sumberdaya kelautan yang terintegrasi, baik dalam kebijakan, maupun pengaturan dan kelembagaan.

Terdapat 15 prinsip dasar yang patut diperhatikan dalam pengelolaan wilayah pesisir dan laut. Kelima belas prinsip dasar ini sebagian besar mengacu pada J.R. Clark (1992): “(1)resources system;(2) the major integrating force;(3)integrated.; (4) focal point;(5) the boundary of coastal zone; (6)conservation of common property resources ;7) degradation of conservation ;(8) inclusion all levels of government;(9) character and dynamic of nature; (10) economic benefits; (11) conservation as main purpose; (12) 
multiple-uses management; (13) multiple-uses utilization;(14)traditional management; (15)environment impact analysis". (J.R. Clark, 1992;327)

Pengelolaan wilayah pesisir dan laut juga mengindahkan prinsip-prinsip pembangunan berkelanjutan dalam The Rio Declaration on Environment and Development (selanjutnya disebut Rio Declaration 1992). Rio Declaration 1992 menetapkan 21 prinsip dengan 7 prinsip utama untuk pembangunan berkelanjutan (sustainable development), yaitu: "(1)principles of interrelationship and integration; (2) inter-and intra-generational equity principles; (3) principles of right to develop; environmental safeguards principles; (4) precautionary principle; (5) polluter pays principle; (6) transparency principle and (7) other process-oriented principles". (Billiana Cicin-Saint and Robert W.Knecht;1998;53)

Selain implementasi prinsip integrated coastal and ocean management dan prinsip sustainable development tersebut, sistem nilai dan etika sangat diperlukan sebagai upaya menyelesaikan sengketa yang terjadi baik secara vertikal maupun horizontal. Implementasi Good Ocean Governance memerlukan partisipasi publik dan kerjasama antar lembaga dan stakeholders.
Kebijakan kelautan nasional dalam Draft Kebijakan Kelautan Indonesia, Tahun 2005, mencakup 2 (dua) dimensi: "Pertama, kepentingan dan kewenangan nasional terhadap wilayah kedaulatan dan yurisdiksi, dan kedua, kepentingan dan keterkaitan Indonesia terhadap peraturan global di perairan laut internasional." (Draft Kebijakan Kelautan Indonesia, 2005)

Oleh karena itu dalam menjalankan kedua dimensi kepentingan tersebut diperlukan suatu kebijakan yang mengatur ruang laut beserta sumberdaya yang terdapat didalamnya. Pengaturan yang diinginkan diwujudkan dalam bentuk tata kelola kelautan sebagai instrumen kebijakan kelautan (ocean policy). Pembangunan kelautan di Indonesia dilakukan dengan melakukan koordinasi dan integrasi di seluruh sektor yang terkait dengan pengelolaan laut, baik Pemerintah maupun sektor swasta. Seperti disebutkan dalam Draft Kebijakan Kelautan Indonesia, bahwa kebijakan kelautan Indonesia dibawah koordinasi Dewan Maritim Indonesia (DMI) melakukan perencanaan, pemantauan dan evaluasi kebijakan kelautan Indonesia.

Selanjutnya tata kelola kelautan (ocean governance) dibangun secara 
sistematik melalui:

pemahaman bahwa pengelolaan pesisir dan laut beserta sumberdaya yang dikandungnya dilakukan secara terpadu; penetapan tujuan dan sasaran pembangunan berkelanjutan; pengembangan nilai dan etika; pengembangan kemampuan menyelesaikan perselisihan (conflict resolution capacity); pengembangan kemampuan perencanaan, pelaksanaan monitoring dan evaluasi secara sinergi; pengembangan partisipasi aktif pemangku kepentingan;penyiapan dan penyelarasan peraturan perundangundangan terkait dengan pengelolaan kelautan; pengembangan kerjasama regional dan internasional berdasarkan prinsip kesetaraan; penguatan dan penataan kelembagaan. Tulisan ini ditekankan pada upaya Indonesia dalam melakukan tata kelola kelautan berdasarkan integrated coastal and ocean management pada pembangunan kelautan berkelanjutan.

\section{Pengaturan Pengelolaan Wilayah Pesisir dan Laut dalam Tata Kelola Kelautan}

Pengelolaan wilayah pesisir dan laut secara efektif dan efisien membutuhkan perangkat peraturan perundang-undangan agar memiliki sifat yuridis-normatif maupun yuridis-sosiologis. (Barry
M.Hager, 2000;3)Berlakunya aturan hukum menjadi sesuatu yang sangat substansial secara teoritis dan paradigmatis bagi pelaksanaan pengelolaan wilayah pesisir dan laut dalam seluruh segmen penyelenggaraan pemerintahan Negara, dan melalui sarana perangkat hukum, pengelolaan pesisir dan laut diharapkan akan terbangun suatu kondisi bermuatan ketertiban, kepastian dan keadilan.

Untuk menjamin ketertiban dan kepastian hukum dalam pelaksanaan pengelolaan wilayah pesisir dan laut berdasarkan integrated coastal and ocean management maka prinsipprinsip dalam integrated coastal and ocean management perlu dituangkan ke dalam peraturan perundang-undangan nasional serta peraturan daerah yang mengatur mengenai pengelolaan wilayah pesisir dan laut.

Aturan hukum pengelolaan wilayah pesisir dan laut berisi ketentuan yang bersifat preventif dan represif. Banyaknya pemanfaatan di wilayah pesisir dan laut memungkinkan banyak sekali konflik yang muncul baik yang sifatnya horisontal maupun vertikal. Untuk mengatasi konflik tersebut diperlukan management conflict yaitu melakukan usaha untuk menyelesaikan konflik dengan menggunakan pendekatan proactive strategy dan reactive strategy. (Adalberto Vallega; 1999;176- 
177)

Peraturan perundang-undangan pengelolaan wilayah pesisir dan laut disusun sebagai upaya pencegahan terhadap konflik yang terjadi diantara pengguna. Upaya penyelesaian konflik dalam pengelolaan wilayah pesisir dan laut dengan pendekatan reactive strategy, yaitu menyelesaikan konflik yang terjadi melalui cara: (a) administrative and juridical procedure dan (b)agreements, arbitration and other similar tools.

Aturan yang sesuai dengan kerangka hukum integrated coastal and ocean management lebih difokuskan pada pendekatan kewenangan daerah dan aspek administrasi. Secara alternatif penyelesaian sengketa dapat dilakukan melalui persetujuan atau perjanjian di antara para pihak, atau penyelesaian melalui arbitrase yang ditunjuk dan disepakati seperti yang diatur dalam undang-undang. Karakteristik pendekatan demikian digunakan dalam penyusunan kerangka hukum untuk pengaturan pengelolaan wilayah pesisir dan laut sesuai dengan integrated coastal and ocean management yang berisi komponen-komponen hukum, sebagai berikut: (Adalberto Vallega; 1999;187)

$$
\text { It consists of two main }
$$
components, international and national law; (1)The justification of international law derives from the consensus by states, which is technically expressed by conventions, treaties and agreements of various kinds; (2)The justification of national law derived from the national sovereignty; (3)As a result, international law is applied in the single country only if the state resolves to incorporate it, through ratification, in its own legal system; (4)The juridical rules are based on the principle of hierarchy according to which the rules included in the lower level cannot derogate from the rules included in the higher level, while the latter may modify the former

Kerangka hukum dalam penyusunan pengaturan pengelolaan wilayah pesisir dan laut di setiap Negara memadukan dan menyelaraskan antara hukum nasional (sesuai dengan struktur hirarkhi perundang-undangan yang berlaku), dan hukum internasional (seperti konvensi, perjanjian internasional, protocol dan lainnya) yang telah diratifikasi dalam bentuk Undangundang atau yang telah menjadi bagian dalam sistem hukum nasional.

Sementara itu disadari bahwa antara sistem hukum nasional dan hukum internasional terdapat perbedaan mengenai daya ikat atau daya berlakunya. Walaupun merupakan bagian dari hukum pada umumnya tapi hukum nasional 
merupakan sistem hukum yang subordinatif sedangkan pada hukum internasional menggunakan pendekatan koordinatif. Hukum internasional dapat berlaku dan mengikat sebagai suatu undang-undang di suatu negara jika telah dilakukan tranformasi dalam bentuk ratifikasi

Pengaturan pengelolaan wilayah pesisir dan laut dapat dibagi dalam beberapa tingkatan, yaitu pada tingkat yang pertama, berisi prinsip-prinsip umum dari pengelolaan pesisir yang dapat ditemukan dalam konstitusi negara, instrumen kebijakan negara dan rencana pembangunan nasional jangka pendek, menengah dan panjang yang merupakan pedoman dalam pelaksanaan peraturan pengelolaan pesisir dan laut (national policy instruments). Sedangkan tingkatan kedua, merupakan peraturan pengelolaan wilayah pesisir dan laut dalam kerangka tata kelola kelautan (basic law) dan undang-undang terkait lainnya. Tingkatan ketiga, merupakan peraturan pelaksana Undangundang dalam bentuk Peraturan Pemerintah atau peraturan lainnya (procedural laws) terkait dengan penyelesaian sengketa dan ganti rugi dalam pengelolaan wilayah pesisir dan laut, dan tingkatan keempat adalah Peraturan Daerah mengenai pengelolaan wilayah pesisir dan laut di daerah (local legislation on coastal and ocean management). (GEF/UNDP/IMO Regional Programme for the Prevention and Management of Marine Pollution in the East Asian Seas, 1999;101-107).

Sebagian Negara melaksanakan integrated coastal management dalam bentuk peraturan perundang-undangan tentang pengelolaan wilayah pesisir dan laut dengan penekanan pada sistem kewenangan kewilayahan/zonasi baik di tingkat nasional dalam bentuk Undangundang ataupun di tingkat lokal dalam bentuk Peraturan Daerah. (Billiana Cicin-Sain and Robert W.Knecht, 1998;33)

Program integrated coastal and ocean management terdiri atas 4 (empat) elemen hierarkhi perencanaan, yaitu rencana strategi, rencana zonasi, rencana pengelolaan, dan rencana aksi. Negaranegara (57 negara) yang telah menerapkan integrated coastal and ocean management untuk mengatasi situasi-situasi khusus di negaranya terus bertambah. Salah satu elemen penting dalam program integrated coastal and ocean management adalah penyusunan suatu rencana zonasi yang mengacu pada penetapan daerah administratif. Penetapan daerah administratif untuk zonasi wilayah pesisir dan laut selain mengacu 
pada Undang-undang Nomor 27 Tahun 2007 tentang PWP-PK juga memperhatikan Undang-undang Nomor 32 Tahun 2004 tentang Pemerintahan Daerah dan Undang-undang Nomor 26 tahun 2004 tentang Penataan Ruang.

Mengacu pada zonasi untuk wilayah pesisir dan laut, maka rejim laut menurut UNCLOS 1982 membaginya ke dalam: (a)Wilayah laut pada kedaulatan negara meliputi Perairan Pedalaman, Perairan Kepulauan dan Laut Territorial; (b)Wilayah laut dengan hak-hak berdaulat (souvereign rights) yang dimiliki oleh negara untuk keperluan eksplorasi dan eksploitasi, konservasi dan pengelolaan sumber kekayaan alam baik hayati maupun nonhayati meliputi Zona Ekonomi Eksklusif (ZEE), dan Landas Kontinen; (c)Wilayah laut yang berada di luar yurisdiksi negara meliputi Laut Lepas dan Kawasan

Dalam pengelolaan sumberdaya di wilayah pesisir dan laut, selain mengacu kepada integrated coastal and ocean management juga memperhatikan rejim hukum yang berlaku di wilayah laut suatu negara. Jika terdapat perbedaan antara hukum nasional dan hukum internasional, maka yang diberlakukan adalah Undang-undang Nomor 27 Tahun 2007 tentang PWP-PK dan Undang-undang Nomor 32 Tahun 2004 tentang Pemerintahan Daerah atau sesuai dengan perjanjian yang telah dibuat oleh kedua negara.

\section{Pengelolaan Wilayah Pesisir dan Laut dalam Pengaturan Penataan Ruang}

Dalam tata kelola kelautan/Ocean Governance ( dalam kamus Besar Bahasa Indonesia digunakan istilah 'pentadbiran lautan') hal yang penting dalam pelaksanaannya adalah menata kelola ruang lautan untuk beragam penggunaan (multiple use of ocean space) dengan maksud untuk (a) menghindari konflik penggunaan ruang lautan dan (b) untuk menjaga kelestarian sumberdaya yang dikandung di dalamnya. Berkaitan dengan Ocean Governance tersebut Jacub Rais mengemukakan 3 konsep penataan ruang lautan: (Jacub Rais, 2005;113) (1)Konsep keterpaduan menata ruang lautan dan daratan melalui pendekatan DAS (Daerah Aliran Sungai); (2)Konsep keterpaduan menata ruang pulau-pulau kecil dan lautan dengan pendekatan bioregionisme yang mengkaitkan karakter fisik oseanografi, atmosfer, perubahan iklim dengan karakter demografi, sosial, ekonomi, budaya yang hidup di pulau-pulau kecil; dan (3)Penataan ruang lautan di luar Laut Teritorial, khususnya di Zona Ekonomi 
Eksklusif menjadi kewajiban negara yang diperoleh dari UNCLOS 1982 untuk pemanfaatan yang lestari dari sumberdaya hayati, khususnya menetapkan penyelenggaraan konservasi sumberdaya hayati dengan menentukan jumlah tangkapan yang diperbolehkan (total allowable catch) seperti yang terdapat dalam Pasal 61 ayat (1) UNCLOS 1982, maupun jenis species yang boleh diambil dengan tujuan untuk memelihara atau memulihkan populasi jenis yang dapat menjamin hasil maksimum yang lestari serta menetapkan kawasan-kawasan konservasi sumberdaya hayati lautan serta tindakan-tindakan manajemennya, seperti yang diatur dalam dalam Pasal 61 ayat(2) UNCLOS 1982.

Penanganan berbagai isu dan pemanfaatan di wilayah pesisir dan laut merupakan salah satu aspek dalam pengelolaan wilayah pesisir dan laut. Sebagai langkah awal yang seharusnya dilakukan oleh negara adalah menatakelola wilayah pesisir dan laut sesuai dengan peraturan perundangan-undangan terpadu mengenai pengelolaan wilayah pesisir dan laut. Pengelolaan wilayah pesisir dan laut dalam penataan ruang wilayah nasional memerlukan pemahaman yang mendalam. Ketentuan Umum UU Nomor 26 Tahun 2007 tentang Penataan Ruang, Pasal 1 ayat (1) menyatakan bahwa "ruang" merupakan wadah yang meliputi ruang darat, ruang laut, dan ruang udara termasuk ruang di dalam bumi sebagai satu kesatuan wilayah, tempat manusia dan makhluk lainnya hidup dan melakukan kegiatan, dan memelihara kelangsungan hidupnya.

Menurut Pasal 1 ayat (2) Undang-Undang Nomor 26 Tahun 2007 tentang Penataan Ruang, tata ruang didefinisikan sebagai "wujud struktur ruang dan pola ruang". Untuk memberikan manfaat yang luas dan berkelanjutan terhadap suatu ruang atau wilayah diperlukan perencanaan terhadap penataan ruang, yang meliputi ruang daratan, ruang lautan, dan ruang udara. Berdasarkan pengertian tersebut maka penataan ruang, dengan ruang sebagai obyek, harus secara integratif mencakup ruang daratan, ruang lautan, dan ruang udara.

Pada hakikatnya penataan ruang adalah suatu kebijakan publik yang bermaksud untuk mengoptimalkan pemanfaatan ruang bagi semua kepentingan para pelaku pembangunan secara terpadu, berdaya guna dan berhasil guna, selaras, seimbang dan berkelanjutan.

Undang-undang Nomor 26 Tahun 2007 tentang Penataan Ruang pada faktanya baru terkait dengan tata ruang daratan, sehingga Pasal 6 ayat (5) dari Undang-undang Nomor 26 Tahun 
2007 tentang Penataan Ruang menyatakan bahwa ruang laut dan ruang udara pengelolaannya diatur dengan undangundang tersendiri. Menurut Haris Syahbuddin, (Haris Syahbuddin, 2007;1) bahwa:“ ... meski secara aktual penataan terhadap ruang laut dan ruang udara hampir tidak pernah dilakukan, namun pencantuman kedua ruang tersebut dalam Undang-undang perlu dilakukan, karena secara geopolitik ketiganya merupakan satu kesatuan geografis yang tidak dapat dipisahkan dan berkait dengan kedaulatan negara."

Sementara itu, UU Nomor 32 Tahun 2004 tentang Pemerintahan Daerah, Pasal 18 Ayat (3) menyatakan bahwa kewenangan daerah untuk mengelola sumberdaya di wilayah laut sebagaimana dimaksud pada ayat (1) meliputi antara lain pengaturan tata ruang (butir c). Selanjutnya, Pasal 18 Ayat (4) menyatakan bahwa kewenangan untuk mengelola sumberdaya di wilayah laut sebagaimana dimaksud pada ayat (3) paling jauh 12 mil laut diukur dari garis pantai dan $1 / 3$ (sepertiga) dari wilayah kewenangan provinsi untuk kabupaten/ kota.

Penataan ruang merupakan sebuah pendekatan dalam pengembangan wilayah yang bertujuan untuk meningkatkan kualitas kesejahteraan masyarakat dan lingkungan hidup. Dalam mencapai tujuan tersebut, dilakukan upaya pengelolaan kawasan melalui pengembangan kegiatan ekonomi masyarakat pada kawasankawasan budidaya dan pelestarian kawasan-kawasan lindung, termasuk yang terdapat di ruang lautan dan kawasan pesisir.

Perencanaan tata ruang merupakan satu tahapan yang sangat penting dalam penyelenggaraan penataan ruang, karena rencana tata ruang merupakan dasar bagi pemanfaatan ruang dan pengendalian pemanfaatan ruang. Implementasi proses-proses penataan ruang tersebut di atas diselenggarakan berdasarkan fungsi utama kawasan, dan wilayah administratif, kegiatan kawasan, dan nilai strategis kawasan yang diatur dalam Pasal 4 UU Nomor 26 Nomor 2007 tentang Penataan Ruang.

Integrated coastal and ocean management selalu terkait dengan zonasi atau penentuan batas-batas pengelolaan wilayah pesisir dan laut di suatu negara. Undang-Undang Nomor 26 Tahun 2007 tentang Penataan Ruang merupakan ketentuan yang mengatur tentang pengelolaan sumberdaya dalam kerangka penataan ruang. Pasal 8 Ayat (2) mengatur mengenai Penataan ruang wilayah nasional, penataan ruang wilayah Propinsi dan penataan ruang wilayah Kabupaten/kota dilakukan secara berjenjang dan komplementer. 
Pada Ayat (3) menyebutkan bahwa Penataan ruang wilayah nasional meliputi ruang wilayah yurisdiksi dan wilayah kedaulatan nasional yang mencakup ruang darat, ruang laut, dan ruang udara, termasuk ruang di dalam bumi sebagai satu kesatuan.

Setiap daerah di wilayah kedaulatan Negara Kesatuan Republik Indonesia mempunyai hak untuk memanfaatkan ruang lautan sesuai dengan peraturan ini. Dalam Pasal 33 Ayat (1) dan Ayat (3) Undang-undang Nomor 26 Tahun 2007 tentang Penataan Ruang, disebutkan bahwa Pemanfaatan ruang dilakukan melalui pelaksanaan program pemanfaatan ruang beserta pembiayaannya, baik pemanfaatan ruang secara vertikal maupun pemanfaatan ruang di dalam bumi.

Pemanfaatan dan pengelolaan ruang wilayah pesisir dan laut secara optimal dapat dilakukan secara terkoordinasi dan terintegrasi sesuai dengan perencanaan ruang wilayah, seperti diatur dalam Pasal 15 Undang-Undang Nomor 26 Tahun 2007 tentang Penataan Ruang. Berdasarkan integrated coastal and ocean management, maka untuk penetapan rencana zonasi wilayah pesisir dan laut di Indonesia seharusnya didasarkan pada Undang-Undang No.26 Tahun 2007 tentang Penataan Ruang, dengan maksud untuk mengatasi konflik pemanfaatan sumberdaya, memandu pemanfaatan zonasi wilayah pesisir dan laut jangka panjang, rencana pembangunan dan pengelolaan sumberdaya.

Klasifikasi zona-zona untuk kawasan pesisir pada dasarnya meng-ikuti Undang-Undang Nomor 26 Tahun 2007 tentang Penataan Ruang dengan modifikasi dan terminologi yang disesuaikan menurut kebutuhan dan ketentuan yang disepakati oleh pemerintah. Dalam Pasal 5 Ayat (2) Undang-Undang Nomor 26 Tahun 2007 tentang Penataan Ruang, menetapkan 2 zona pengelolaan yang dinamakan kawasan lindung dan kawasan budidaya. Pemanfaatan wilayah pesisir sesuai dengan zona yang ditetapkan menjelaskan tujuan utama pemanfaatan sumberdaya yang ada dalam satu wilayah geografis sesuai dengan pemenuhan kebutuhan masyarakat lokal yang ada di wilayah zona tersebut.

Perencanaan tata ruang pesisir dan laut harus diletakkan dalam satu kerangka sistem perencanaan wilayah darat, laut dan udara yang disusun sesuai dengan peraturan perundang-undangan. Batas wilayah perencanaan, termasuk batas laut, disesuaikan dengan batas kewenangan Daerah Propinsi dan Daerah Kabupaten/Kota sebagaimana diatur dalam UU Nomor 32 Tahun 2004 tentang Pemerintahan Daerah.

Berdasarkan Pasal 18 Ayat (1) 
UU Nomor 32 Tahun 2004 tentang Pemerintahan Daerah, disebutkan bahwa daerah yang memiliki wilayah laut diberikan kewenangan untuk mengelola sumberdaya di wilayah laut. Sedangkan, menurut Pasal 18 Ayat (4) UU Nomor 32 Tahun 2004 tentang Pemerintahan Daerah, kewenangan untuk mengelola sumberdaya di wilayah laut paling jauh 12 (dua belas) mil laut diukur dari garis pantai ke arah laut lepas dan /atau ke arah perairan kepulauan untuk provinsi dari 1/3 (sepertiga) dan wilayah kewenangan provinsi untuk kabupaten/kota.

Untuk memelihara konsistensi legislatif, Pemerintah, dalam hal ini Menteri Kelautan dan Perikanan Republik Indonesia dalam penyusunan peraturan pengelolaan wilayah pesisir dan penetapan zonasi pesisir mengikuti aturan sesuai dengan Undang-undang Nomor 32 Tahun 2004, Undang-undang Nomor 26 Tahun 2007 tentang Penataan Ruang, Undang-undang Nomor 5 Tahun 1990 tentang Konservasi Sumberdaya Alam Hayati dan Ekosistemnya, Undang-undang Nomor 6 Tahun 1996 tentang Perairan Indonesia serta Undang-Undang Nomor 27 Tahun 2007 tentang PWP-PK.

Undang-undang Nomor 27 Tahun 2007 tentang PWP-PK hanya mengamanatkan bahwa dalam pe- rencanaan zonasi wilayah pesisir harus diserasikan dan diseimbangkan dengan rencana tata ruang wilayah (RTRW) pemerintah provinsi atau pemerintah kabupaten/kota dan tidak diuraikan tentang pembagian zonasi. Sementara itu zona dan sub-sub zona yang ditetapkan di wilayah pesisir diatur dalam Undangundang Nomor 5 Tahun 1990 tentang Konservasi SumberDaya Alam dan Ekosistemnya dan Undang-undang Nomor 26 Tahun 2007 tentang Penataan Ruang.

Pembagian zonasi pada suatu wilayah tertentu, secara keseluruhan memperhatikan batas-batas secara visual untuk pemanfaatan setiap zona yang ditentukan dengan garis yang jelas antara dua atau tiga pulau, semenanjung, bidang dari karang atau garis pantai, serta habitat pesisir dan laut atau struktur yang permanen seperti tiang atau menara telekomunikasi yang merupakan batas dari Negara, antar Provinsi, Kabupaten/ Kota yang berhadapan atau berdampingan akan memperkecil potensi konflik kepentingan (conflict of interest) dan tumpang tindih antar sektor dan stakeholders lainnya dalam pengelolaan dan pemanfaatan wilayah pesisir dan laut. (MCRMP, 2005;22)

Kondisi ini muncul sebagai konsekuensi beragamnya sumberdaya pesisir dan laut yang ada serta 
karakteristik wilayah pesisir dan laut yang "open access" sehingga mendorong wilayah pesisir dan laut menjadi salah satu lokasi utama bagi kegiatankegiatan beberapa sektor pembangunan (multi-use). Selain itu, konflik kepentingan tidak hanya terjadi antar pengguna, yakni sektoral dalam pemerintahan dan juga masyarakat setempat dan pihak swasta, namun juga antar pengguna.

Potensi konflik kewenangan (jurisdictional conflict) dalam pengelolaan dan pemanfaatan wilayah pesisir dan laut akan muncul sebagai konsekuensi tidak berhimpitnya pembagian kewenangan yang terbagi menurut administrasi Pemerintah Provinsi dan Kabupaten/Kota dengan kepentingan wilayah pesisir dan laut tersebut yang seringkali lintas wilayah otonom. Konflik kewenangan antar Undang-Undang juga terjadi pada bidang pengaturan tata ruang wilayah pesisir dan laut Di dalam Undang-Undang Nomor 26 Tahun 2007 tentang Penataan Ruang ditentukan bahwa ruang laut dan udara pengelolaannya diatur dengan UndangUndang tersendiri (Pasal 6 Ayat 5), sebaliknya, di dalam Pasal 18 ayat (4) Undang-Undang Nomor 32 Tahun 2004 tentang Pemerintah Daerah ditentukan bahwa pengelolaan sumberdaya di wilayah laut sejauh 12 mil merupakan kewenangan provinsi. Wilayah pengelolaan di setiap daerah diatur dan ditata sesuai dengan RTRW Propinsi/kabupaten atau Kota, sehingga kewenangan daerah Propinsi, Kabupaten/Kota dapat ditata sesuai dengan penataan ruang wilayah.

Konflik kewenangan antar undangundang ini akan berpengaruh pada rendahnya tingkat kesejahteraan masyarakat pesisir yang bermatapencaharian di sektor-sektor non-perkotaan, karena ketiadaan peraturan perundangan sebagai pelaksanaan kewenangan Pemerintah Pusat dan Provinsi/Kabupaten/Kota.

Lemahnya perangkat hukum pemanfaatan sumberdaya pesisir dan laut serta penegakan hukumnya menyebabkan masih banyaknya pemanfaatan sumberdaya yang tidak terkendali. Perlunya keterpaduan peraturan perundang-undangan mengenai pengelolaan wilayah pesisir dan laut akan menentukan keberhasilan pelaksanaan pengelolaan wilayah pesisir dan laut.

Tata Kelola Kelautan dalam Rangka Pembangunan Kelautan Berkelanjutan Fungsi Pesisir dan Laut dalam Pembangunan Kelautan Berkelanjutan

Menyadari bahwa konflik yang terjadi antara kepentingan pembangunan ekonomi dengan pelestarian lingkungan di dunia selama ini tidak pernah selesai, PBB melalui The World Commission on Environment and Development 
(Brundtland Commission), 1987, (WCED,1987) memberikan pengertian dan prinsip-prinsip untuk pembangunan berkelanjutan. Menurut Brundtland Commission, bahwa sustainable development is vital to the wellbeing of humanity not only today but in the context of the future generations. (Munro,R.D.;1986)

Pembangunan berkelanjutan mengandung 3 (tiga) unsur utama yang meliputi dimensi ekonomi, ekologi, dan sosial. (Rohmin Dahuri I, 2003;89) Pembangunan suatu kawasan dapat dikatakan berkelanjutan, apabila secara ekonomis dapat efisien serta layak, secara ekologis lestari (ramah lingkungan), dan secara sosial berkeadilan.

Dalam mengelola laut sebagai wilayah ada dua hal pokok yang perlu diperhatikan (DKP, 2005;3), yaitu, secara eksternal adalah menata batasbatas maritim dengan negara-negara tetangga sesuai dengan ketentuan internasional yang berlaku dan kedua, secara internal adalah menata wilayah laut khususnya batas-batas peruntukan ruang laut sebagai suatu langkah pengaturan untuk menghindari konflik pemanfaatan ruang laut antar sektor yang memiliki kepentingan dalam mengelola sumberdaya kelautan.

Pembangunan kelautan berkelanjutan bersifat multidimensi, yaitu mewujudkan kelestarian pembangunan suatu kawasan baik secara politik, ekonomi, sosial dan budaya secara berkelanjutan. Laut dipandang sebagai pemersatu bangsa Indonesia dengan wilayah kedaulatan yang harus dijaga, dilindungi dan dipertahankan secara bersama .

Perwujudan ketiga dimensi pembangunan kelautan berkelanjutan tersebut secara seimbang dapat diintegrasikan dengan konsep integrated coastal and ocean management. Implementasi pembangunan berkelanjutan dalam pengelolaan pembangunan sumberdaya kelautan, secara teknis dapat diartikan bahwa "pembangunan kelautan berkelanjutan" (sustainable marine development) adalah suatu upaya pemanfaatan sumberdaya alam dan jasa-jasa lingkungan yang terdapat dalam kawasan pesisir dan laut untuk kesejahteraan manusia, terutama stakeholders, sehingga laju (tingkat) pemanfaatan sumberdaya alam dan jasa-jasa lingkungan, tidak melebihi daya dukung (carrying capacity) yang mampu disediakan oleh kawasan pesisir dan laut.

Wilayah pesisir dan laut selain menyediakan berbagai manfaat seperti yang disebut diatas, juga digunakan untuk aktivitas pembangunan. Penggunaan wilayah pesisir dan laut secara berlebihan akan mengalami menimbulkan degradasi fisik habitat sehingga kemampuan 
wilayah pesisir dan laut sebagai penyangga kehidupan global akan mengalami penurunan.

Seperti disebutkan dalam Pasal 4 Undang-Undang Nomor 27 Tahun 2007 tentang PWP-PK bahwa tujuan dilakukannya pengelolaan wilayah pesisir dan laut dalam rangka pembangunan kelautan berkelanjutan adalah : (a)melindungi, mengonservasi, merehabilitasi, memanfaatkan, dan memperkaya Sumber Daya Pesisir dan Pulau-pulau Kecil serta sistem ekologisnya secara berkelanjutan; (b)menciptakan keharmonisan dan sinergi Pemerintah dan Pemerintah Daerah dalam pengelolaan Sumber Daya Pesisir dan Pulau-pulau Kecil

\section{Tata Kelola Kelautan Dalam Peraturan Perundang-undangan Nasional.}

Pembangunan kelautan merupakan perwujudan amanat Pasal 33 Undangundang Dasar (UUD) 1945, terkandung upaya pemanfaatan kekayaan sumberdaya alam secara lestari, dan berkelanjutan serta mendayagunakan sumberdaya manusia (SDM), modal, dan IPTEK, yang ditujukan bagi sebesar-besar kemakmuran rakyat. Pembangunan kelautan diarahkan untuk mampu dalam mengelola dan memanfaatkan kekayaan perairan
Indonesia serta menggunakannya sebagai sarana dan media perdagangan antar wilayah ataupun antar negara bagi kepentingan bangsa.

Dalam mewujudkan cita-cita nasional tersebut perlu adanya komitmen pihak pemerintah. Komitmen ini disusun dalam suatu Kebijakan Kelautan Indonesia pada Tahun 2005. Kebijakan ini merupakan langkah awal dalam pelaksanaan dan meletakkan kerangka dasar pembangunan kelautan Indonesia di masa datang.

Kebijakan Kelautan Indonesia dapat mewujudkan pembangunan kelautan yang multisektoral melalui kesamaan visi, misi, strategi pembangunan nasional dengan mengelola aset lingkungan dan sumberdaya kelautan yang sangat penting bagi bangsa Indonesia di masa kompetisi global antar bangsa.

Kebijakan Kelautan Indonesia juga harus disinergikan dengan pembangunan ekonomi yang mengembangkan potensi kelautan (Ocean economics) dan ocean governance yang mendorong terjadinya demokratisasi dan good governance. (Harsono, 2007; 23)

Dengan adanya otonomi daerah yang tertuang dalam Undang-Undang Nomor 32 Tahun 2004 tentang Pemerintahan Daerah, dan pelaksanaan program Marine And Coastal Resources 
Management Project (MCRMP), dan Undang-undang Nomor 27 Tahun 2007 tentang PWP-PK diharapkan menjadi payung hukum dan dapat menjadi guideline bagi Pemerintah Daerah dan sekaligus mensinergikan pembangunan kelautannya dengan Pemerintah Pusat, sehingga implementasi pembangunan kelautan dapat dilakukan oleh daerah dalam kerangka NKRI .

Kebijakan Kelautan Indonesia disusun dengan memperhatikan asasasas pembangunan berkelanjutan (sustainable development) sebagai berikut: asas kedaulatan, keterpaduan, berbasis ekosistem dan ekologi, kemandirian, kepribadian, kerakyatan, kepentingan nasional, dan berkeadilan. Selain itu juga kebijakan kelautan di Indonesia juga memperhatikan asas-asas yang tercantum dalam Undang-Undang Nomor 27 Tahun 2007 tentang PWP-PK.

Berdasarkan asas tersebut, pemerintah menetapkan tujuan Kebijakan Kelautan Indonesia adalah: (1)Mewujudkan Indonesia menjadi negara kelautan yang maju, kuat, mandiri, berbasiskan kepentingan nasional, dengan mengoptimalkan pemanfaat -an sumber kekayaan laut secara berkelanjutan dengan mempertimbangkan generasi mendatang; (2)Meningkatkan kapasitas SDM yang berwawasan kelautan sehingga mampu mendukung pembangunan kelautan di Indonesia secara optimal; (3)Menumbuhkan dan mengembangkan budaya dan wawasan bahari bagi masyarakat dan pemerintah serta seluruh anak bangsa agar pembangunan Indonesia berorientasi kelautan (marine based socio-economic development); (4)Menerapkan, melindungi, memelihara dan mengamankan kedaulatan dan kepentingan Indonesia atas kesatuan wilayah, politik, ekonomi dengan memperhatikan kewajiban-kewajiban sesuai ketentuan internasional.

Kebijakan Kelautan Indonesia didasarkan pada pendekatan pengelolaan wilayah pesisir dan laut terpadu (integrated coastal and ocean management), mengintegrasikan berbagai perencanaan yang disusun dan melibatkan pemerintah pusat dan daerah sehingga terjadi keharmonisan dan saling penguatan (alignment) pemanfaatannya. Kebijakan kelautan berkelanjutan diharapkan dapat mengharmonisasikan antara kepentingan pembangunan ekonomi dan pelestarian sumberdaya laut dengan memperhatikan karakteristik dan keunikan wilayah untuk kepentingan generasi sekarang dan generasi mendatang.

Kebijakan Kelautan Indonesia disusun sebagai arahan strategis dan komprehensif dalam rangka mewujudkan visi dan misi pembangunan kelautan 
nasional hingga Tahun 2025. Pembangunan kelautan ke depan diarahkan pada pembangunan berkelanjutan berdasarkan pada pengelolaan sumberdaya laut berbasiskan ekosistem yang meliputi aspek-aspek politik, ekonomi, lingkungan, sosial budaya, pertahanan keamanan, teknologi, SDM dan kelembagaan.

Untuk mewujudkan optimalisasi pemanfaatan sumberdaya kelautan dan menghindari konflik kepentingan seperti di atas, maka diperlukan kebijakan yang menyeluruh dan terpadu terhadap peraturan perundang-undangan sektoral di bidang kelautan.

\section{Tata Kelola Kelautan dalam Rangka Pembangunan Kelautan Berkelanjutan}

Sumberdaya kelautan di Indonesia hingga saat ini belum dapat dimanfaatkan dengan maksimal. Sumberdaya kelautan dapat dikelola dan dimanfaatkan melalui berbagai jenis kegiatan seperti komoditi, usaha dan jasa, seperti perikanan tangkap dan budidaya, transportasi, pertambangan, wisata bahari, dan pembangkit energi.

Namun demikian pengelolaan sumber daya kelautan juga memerlukan kebijakan pemerintah dalam hal investasi, dukungan teknologi dan sumberdaya manusia (SDM) yang memadai. Disamping itu juga bahwa pengelolaan sumberdaya kelautan tidak dapat lepas dari peraturan hukum internasional, karena laut Indonesia merupakan bagian dari laut dunia. Beberapa kebijakan pengelolaan sumberdaya kelautan yang memerlukan status hukum yang jelas, yaitu:

\section{Penataan Batas Maritim}

Penataan batas maritim bagi NKRI merupakan tantangan nyata dan tanggung jawab besar untuk menyelesaikannya, karena penataan batas maritim terkait dengan kedaulatan dan yurisdiksi negara. Sesuai dengan konsep integrated coastal and ocean management, harus ada suatu pewilayahan (zonasi) pembangunan sesuai dengan kondisi fisik alam, potensi pembangunan (sumberdaya alam dan jasa-jasa lingkungan) yang tersedia dan kondisi sosio-kultural masyarakatnya.

Atas dasar karakteristik biofisik dan sejalan dengan otonomi daerah sebagaimana tertuang dalam Undangundang Nomor 32 Tahun 2004 tentang Pemerintahan Daerah, Undang-undang Nomor 26 Tahun 2007 tentang Penataan Ruang, dan Undang-undang Nomor 27 Tahun 2007 tentang PWP-PK, maka guna mewujudkan pembangunan kelautan secara berkelanjutan sesuai dengan tata kelola kelautan, Pemerintah 
Daerah (Provinsi/Kabupaten/Kota) sesuai dengan kewenangan wilayah masing-masing difasilitasi oleh Pemerintah Pusat mengadakan (Subandono Diposaptono,2005;12) inventarisasi dan pemetaan, menyusun rencana investasi dan menyusun kebijakan pengelolaan sumberdaya alam dan lingkungan

\section{Pemanfaatan Ruang di Laut}

Ruang laut memungkinkan pemanfaatan lebih dari satu peruntukan. Permukaan laut dapat dimanfaatkan sebagai jalur pelayaran. Ruang kolom air dapat dijadikan sebagai lokasi penangkapan ikan, lokasi selam wisata bahari, atau wilayah konservasi. Ruang di permukaan dasar laut dapat dimanfaatkan sebagai lokasi peletakan jalur kabel ataupun jalur pipa bawah air, disamping dapat pula dimanfaatkan sebagai lokasi penambangan juga perikanan (untuk jenis sedenter).

Pemanfaatan ruang laut yang tidak terintegrasi akan menimbulkan konflik pemanfaatan. Penataan ruang laut di Indonesia masih belum ditetapkan secara tegas dan tercermin pada kebijakan terkait dengan pengelolaan laut yang berkembang saat ini. UndangUndang Nomor 26 Tahun 2007 tentang Penataan Ruang belum menjawab secara jelas mengenai penataan ruang wilayah laut di Indonesia dan masih akan diatur dalam undang-undang tersendiri. Laut di Indonesia pada kenyataannya dikelola oleh beberapa institusi yang belum menunjukkan kebijakan pengaturan yang selaras. Produk hukum yang ada, sebagian besar disusun untuk mengatur sektor dalam pemanfaatan sumberdaya laut dengan penekanan pada masingmasing kepentingan sektoral.

\section{Otonomi Daerah}

Undang-Undang Nomor 32 Tahun 2004 tentang Pemerintahan Daerah membawa perubahan dalam pelaksanaan pemerintahan baik di pusat dan daerah, seperti diungkapkan oleh Arif Satria, (Arif Satria, 2002; 1-5) bahwa: "Perubahan paradigma pembangunan yang bersifat terpusat (sentralistik) telah mengalami koreksi dengan munculnya lingkungan strategi baru berupa pendekatan pembangunan yang bersifat desentralistik."

Perubahan ini membawa konsekuensi berupa pendelegasian kewenangan pemerintah dari pusat ke daerah, yang lebih dikenal sebagai otonomi daerah. Kebijakan pelimpahan wewenang ini berdampak signifikan terhadap pengelolaan dan pemanfaatan sumberdaya kelautan. Makna kewenangan merujuk pada pemberian hak dalam pengelolaan dan pemanfaatan. Pemahaman ini berarti bahwa batasan 12 mil bagi provinsi dan $1 / 3$ nya bagi 
kabupaten/kota bukan batasan teritorial yang bersifat kedaulatan, tetapi hanya batasan dalam arti kewenangan untuk mengelola dan memanfaatkan sumberdaya yang terkandung di dalamnya. Seperti yang terdapat dalam Pasal 18 ayat (4) UndangUndang Nomor 32 Tahun 2004 tentang Pemerintahan Daerah, yang menentukan bahwa daerah diberi kewenangan untuk mengelola sumberdaya di wilayah laut paling jauh 12 (dua belas) mil laut diukur dari garis pantai ke arah laut lepas dan/atau ke arah perairan kepulauan untuk propinsi dan $1 / 3$ (sepertiga) dari wilayah kewenangan provinsi untuk kabupaten/ kota.

Dengan demikian, tidak ada kedaulatan atas wilayah laut bagi daerah yang bersifat parsial karena secara yuridis formal kedaulatan teritorial atas wilayah lautan Indonesia merupakan kedaulatan NKRI. Pelimpahan kewenangan ini memiliki dampak yang berkaitan langsung dengan kelembagaan, baik di pusat maupun di daerah.

Penguatan dan pengembangan kelembagaan terpadu di tingkat nasional, lokal/tradisional dalam pengelolaan dan pemanfaatan sumberdaya kelautan sangat diperlukan agar menjadi signifikan dalam konteks implementasi otonomi daerah.

Implementasi dari penguatan kelembagaan akan melahirkan pluralisme dalam menyusun peraturan-peraturan di daerah yang langsung berkaitan dengan pengelolaan dan pemanfaatan sumberdaya alam dan lingkungan di wilayah laut. Hal ini karena ada perbedaan sistem nilai, sistem sosial-budaya, kondisi sosial ekonomi, dan politik yang berkembang di suatu daerah. Dengan demikian, sistem yang terbangun dalam otonomi daerah mampu meningkatkan partisipasi masyarakat sebagai subyek pembangunan untuk mencapai kemandirian secara ekonomi dan politiknya.

\section{PENUTUP}

MOD yang dihasilkan dalam WOC merupakan langkah awal yang harus diikuti dengan tindak lanjut, sehingga memberikan manfaat bagi semua negara, khususnya kepada negara kepulauan yang sedang berkembang. Implementasi MOD masih bergantung pada pertemuan negara-negara dalam United Nations Framework Convention on Climate Change/UNFCCC di Kopenhagen, Denmark, Desember 2009 mendatang yang merupakan kelanjutan UNFCCC di Bali 2007.

Konferensi Kelautan Dunia (WOC) 2009 di Manado merupakan awal yang sangat menentukan bagi masyarakat dunia pada umumnya dan Indonesia pada khususnya. Mengingat 
Indonesia merupakan salah satu Negara kepulauan yang terbesar di dunia, maka perhatian terhadap laut hendaknya dimulai dari sekarang. Tidak ada kata terlambat untuk memulai kebaikan jika untuk keselamatan dan keutuhan wilayah NKRI. Pemanasan global menyebabkan permukaan suhu panas bumi, sehingga akan berakibat pada naiknya permukaan air laut. Kondisi ini akan sangat membahayakan bagi wilayah Indonesia yang 2/3 wilayahnya adalah laut. Terutama keberadaan pulaupulau kecil terluar yang merupakan titik koordinat dan /atau sebagai base point pengukuran lebar laut wilayah suatu negara.

Tata kelola kelautan sebagai bagian dari Ocean Policy disusun dalam suatu kerangka hukum pengelolaan wilayah pesisir dan laut dengan menggunakan konsep integrated coastal and ocean management. Sebagai upaya untuk mewujudkan pembangunan kelautan berkelanjutan sesuai kebijakan kelautan perlu untuk menuangkan prinsip-prinsip dalamIntegrated Coastal and ocean Management dan Sustainable Development, dalam undang-undang sektoral terkait yang mengatur mengenai pengelolaan wilayah pesisir dan laut.

Hal ini dimaksudkan sebagai upaya mengatasi konflik dalam pemanfaatan atau eksploitasi sumberdaya pesisir dan laut yang berlebihan. Pengaturan pengelolaan wilayah pesisir dan laut memadukan dan menyelaraskan antara aturan-aturan hukum internasional dan hukum nasional untuk mewujudkan pembangunan kelautan berkelanjutan.

\section{DAFTAR PUSTAKA}

Cicin-Saint, Billiana and Robert W.Knecht. (1998). Integrated Coastal and Ocean Management, Concept and Practices, Island Press, Washington, D.C, Covelo, California

Dahuri, Rochmin ,et.al. (2001). Pengelolaan Sumberdaya Wilayah Pesisir dan Lautan Secara Terpadu, Pradnya Paramita, Jakarta

Dahuri, Rokmin. (2003). Paradigma Baru Pembangunan Indonesia Berbasis Kelautan, Orasi Ilmiah, Institut Pertanian Bogor

M.Hager, Barry. (2000). The Rule of Law: A Lexicon for Policy Makers, the Mansfield Center for Programs of Direct the Public Policy and Outrech Programs of The Maureen and Mike Mansfield Foundation

Munro, R.D. \& Lammers, J.G. (1986). Environmental Protection and Sustainable Development, Legal Principles and Recommendation, Graham \& Trotman/Martinus Nijhoff, Members of the Kluwer Academic Publichers Group, 
London/Dordrecht/Boston

Satria, Arif, et al. (2002). Мenuju Desentralisasi Kelautan, Pusat Kajian Agraria ITB, Partnership for Governance Reform in Indonesia, dengan PT. Pustaka Cidesindo

Vallega, Adalberto. (1999). Fundamental of Integrated Coastal Management, Kluwer Academic Publishers

Buku Saku MCRMP. (2005). Sekilas Biodata PMO dan Konsultan MCRMP, Biodata KPA Propinsi dan Kabupaten/Kota, Jakarta,

Departemen Hukum dan Hak Asasi Manusia dan Coastal Resources Management Project. (2005). Narasi, Inisiatif Harmonisasi Sistem Hukum Pengelolaan Wilayah Pesisir Indonesia, Kerjasama Kementerian Perencanaan Pembangunan Nasional, Jakarta

Draft Kebijakan Kelautan Indonesia, DKP, Tahun 2005.

Manual on Strategis. (1999). Tools and Techniques for Implementing International Conventions on Marine Pollution in the East Asian Region, GEF/UNDP/IMO Regional Programme for the Prevention and Management of Marine Pollution in the East Asian Seas, Philippines,

Agenda 21, Earth's Action Plan. (2002). IUCN Environmental Policy and Law Paper No.27, Nicholas A. Robinson, editor, Under the auspices of The Commission on
Environmental Law of IUCN-The World Conservation Union,

Agenda 21 Indonesia. (1997). Publikasi Awal, Strategi Nasional Untuk Pembangunan Berkelanjutan, Kantor Menteri Negara Lingkungan Hidup

WCED. ((1987). dalam publikasi “Our Common Future"

Diposaptono, Subandono. (2005). Rencana Zonasi, Ditjen Pesisir dan Pulau-pulau Kecil, Makalah, Proyek Pengelolaan Sumberdaya Pesisir dan Laut

Syahbuddin, Haris. (2007). "Penataan Ruang Wilayah : Perjalanan Panjang Bangsa”, Inovasi Online, Edisi Vol.7/XVIII/Juni

Soepardjo, Harsono. (2007). Kebijakan Kelautan Indonesia, cdc.eng.ui. ac.id/articleview/2437/1/2

Kamus Besar Bahasa Indonesia, Edisi Terbaru, Gita Media Press, Tanpa Tahun.

\section{PERATURAN PERUNDANG- UNDANGAN:}

Undang-Undang Nomor 5 Tahun 1990, tentang Konservasi Sumberdaya Alam Hayati dan Ekosistemnya, Lembaran Negara Republik Indonesia Tahun 1990 Nomor 49, Tambahan Lembaran Negara Republik Indonesia Nomor 3419

Undang-Undang Nomor 32 Tahun 2004, tentang Pemerintahan Daerah, 
Lembaran Negara Republik Indonesia Tahun 2004 Nomor 125, Tambahan Lembaran Negara Republik Indonesia Nomor 4437

Undang-Undang Nomor 26 Tahun 2007, tentang Penataan Ruang, Lembaran Negara Republik Indonesia Tahun 2007 Nomor 68, Tambahan Lembaran Negara Republik Indonesia Nomor 4725

Undang-Undang Nomor 27 Tahun 2007, tentang Pengelolaan Wilayah Pesisir dan Pulau-pulau Kecil, Lembaran Negara Republik Indonesia Tahun 2007 Nomor 84, Tambahan Lembaran Negara Republik Indonesia Nomor 4739

Undang-Undang Nomor 17 Tahun 1985, tentang Pengesahan United Nations Convention on the Law of the Sea/Konvensi PBB tentang Hukum Laut, Lembaran Negara Republik Indonesia Tahun 1985 Nomor 76, Tambahan Lembaran Negara Republik Indonesia Nomor 3319 